\title{
Impact Assessment of Abiotic Production Constrains of Faba Bean (Vicia faba L.) and Breeding Mechanisms for Acid Soil, Drought and Waterlogging Affected Environments
}

\author{
Mesfin Tadele \\ Ethiopian Institute of Agricultural Research, Holetta Agricultural Research Center, P. O. Box 2003, Addis \\ Ababa, Ethiopia
}

\begin{abstract}
Faba bean is one of the oldest crops grown in Ethiopia. It is used as a source of protein in human diets, as fodder and a forage crop for animals and for soil fertility improvement. Its production in Ethiopia is totally rainfed on nitosols, cambisol and vertisol. Ethiopia is the second largest faba bean producer next to China. However, its productivity has remained very low compared to the potential due to biotic and abiotic stresses coupled with poor crop management practices provided by farmers. Thus, this review deals with impacts of abiotic stress on the growth and performance of faba bean and its remedial measures for continues production. Among the abiotic stresses soil acidity, drought and waterlogging provide a hostile environment for faba bean growth. Both soil acidity and drought are worldwide problem and sensitivity to acid soils limits the usage of faba bean in some cropping systems. Hence, the low production of faba bean is attributed by high moisture stress in the northern block of the country and soil acidity in the western and central highlands of Ethiopia. As chocolate spot the major faba bean disease it can be aggravated by any abiotic stress. To overcome low production of faba bean on acidic soils liming is an immediate option but choice of acid-tolerant varieties may further reduce the amounts of lime requirement and makes farming more attractive. Likewise, terminal drought can be managed by early planting and use of early varieties. Additionally, physiological traits like deep root, stomatal conductance and osmoregulation enables as drought resistant mechanisms. Breeding faba bean for acid soil, drought and water logging problem areas is the best option for sustainable production of the crop and to address the resource poor farmers that produce faba bean in their cropping system.
\end{abstract}

Keywords: Abiotc stress, Breeding, Drought, Faba bean, soil acidity, Waterlogging

DOI: $10.7176 / \mathrm{JBAH} / 10-11-06$

Publication date:June $30^{\text {th }} 2020$

\section{Introduction}

Faba bean belongs to family Fabaceae, subfamily Faboideae, tribe Vicieae, genus Vicia and species $V$. faba. It is an annual legume botanically known as Vicia faba L. (Hanelt and Mettin, 1989). It is one of the earliest domesticated food legumes in the world, probably in the late Neolithic period (Metayer, 2004) after chickpea and pea (Torres et al., 2006). Faba bean is assigned to the Central Asian, Mediterranean and South American centers of diversity and believe to be a native to North Africa and Southwest Asia, and extensively cultivated elsewhere (Zohary and Hopf, 2000). Afghanistan and Ethiopia are postulated as secondary centers of diversity for faba bean and it is believed that the crop was introduced to Ethiopia from the Middle East via Egypt around 5000 B.C (Asfaw et al., 1994).

Globally faba bean is produced in different agro-ecological regions in which Ethiopia is the second largest producer next to China (FAOSTAT, 2018). In Ethiopia, faba bean is the leading pulse category in area coverage and total production (CSA, 2017). It is mainly cultivated in the mid to high altitude areas of Ethiopia with elevations of 1800-3000 meter above sea level (Mussa and Gemechu, 2006). Its production in Ethiopia is totally rainfed on nitosols and cambisol type of soils (Gemechu and Mussa, 2002) and currently on Vertisol too (Tadele, 2019).

Faba bean has multiple advantages. It is consumed as dry seeds, green vegetable, or as processed food. Its products are a rich source of high-quality protein in the human diet that ranges from $24-33 \%$ (Winch, 2006) and used as animal feed (Sainte, 2011). It might substitute meat where there is demand for non-animal protein sources (Crépona et al., 2010). This crop is widely used in rotation with cereals as it improves soil fertility and serves as a source of cash to the farmers and foreign currency to Ethiopia (Tadele, 2019).

Despite its diverse benefits and the availability of high yielding varieties ( $>3 \mathrm{t} / \mathrm{ha}$ ) (MoALR. 2017), the productivity of faba bean has remained very low compared to the potential. The average national yield of faba bean under small-holder farmers is 2.11 tha $^{-1}$ (CSA, 2017). The low productivity of the crop is attributed to susceptibility to biotic and abiotic stresses (Mussa et al., 2008) coupled with poor crop management (Gemechu et $a l ., 2016)$. Thus, faba bean breeding for abiotic stress tolerance is very important. Therefore, this paper is reviewed with the objective to assess abiotic factors that limits the production and productivity of faba bean in Ethiopia and remedial measures. 


\section{Importance and Production of Faba Bean}

Various literatures confirmed that faba bean has a versatile uses. It is used as a source of protein in human diets, as fodder and a forage crop for animals, and for available nitrogen in the soil (Maalouf, 2011). Faba bean seed is generally recognized of good nutritional value in human foods or animal feeds. This is the result of its valuable and digestible major seed components, starch and proteins (Duc et al., 2011). Additionally, it is used for green manure production or as a legume in rotation with cereals (McVicar et al., 2013). Faba bean is a common breakfast food in the Middle East, Mediterranean region, China and Ethiopia (Bond et al., 1985). In Ethiopia and other countries it is consumed in different forms such as Eshete (green seed), Kolo (soaked and roasted), wot (sauces) made of shiro (powdered seeds) with injera and bread, and Nifro (cooked seeds) or mixed with vegetables etc. Faba bean can provide a very good supplement to weaning foods of high nutritive value (Ali et al., 1982).

Faba bean is the leading pulse category of Ethiopia in area coverage and total production that accounts about 0.44 million ha $(27.34 \%$ area coverage of pulses) and about 0.92 million tons $(30.95 \%$ of the total pulse crops production) (CSA, 2017). It produced in different regions of the country like Oromia, Amahara, Tigray, Southern nation nationalities and peoples region (SNNPR) and Benishangul-Gumuz regional states. Oromia Regional State is the largest producer in the country followed by Amhara region. The two regions together share about $83 \%$ of the country's faba bean production (CSA, 2017).

\section{Production Constraints of Faba Bean in Ethiopia}

The majority of Ethiopian farmers cultivate local faba bean varieties (Thijssen et al., 2008). However, most local faba bean landraces are highly susceptible to disease and low yielding (Sahile et al., 2008) and also susceptible to both biotic and abiotic factors (Mussa et al., 2008; Gemechu et al., 2016). Faba bean varieties, combining disease resistance with desirable traits like large seed sizes and high yield, are more preferred by the farmers in Ethiopia (IFPRI, 2010). As a result there are more than 30 improved faba bean varieties which are adapted to different agroecology that have different merits (Tadele, 2019). Despite the number of improved varieties, the productivity of faba bean in Ethiopia is quite low (2.11 tha $\left.{ }^{-1}\right)$ (CSA, 2017) compared to Egypt and United Kingdom 3.47 and 3.83 tha $^{-1}$, respectively (FAOSTAT, 2018).

The major production constraints of faba bean that attributes to lower productivity and product quality in Ethiopia are related with inherent biological limitations (Mussa and Gemechu, 2006), biotic stresses, abiotic stresses and poor crop management practices (Gemechu et al., 2016). The growth and yield of faba bean is determined by abiotc factors like soil acidity, Waterlogging, frost, deficiency of soil nutrients, low external inputs with poor agronomic practices provided by the farmers and moisture stress (Gemechu et al., 2016). Factors like climatic, edaphic, and management practices that are not independent of each other and interact to affect the chemical characteristics of the soil (Jensen et al., 2010). Among abiotic stresses soil acidity is the major production limiting factors of faba bean in Ethiopia (Asefa et al., 2010). Soil acidity has a dramatic impact on most chemical and biological processes of a crop (Jensen et al., 2010).

Environmental factors (light, temperature, water and soil) greatly affect plant growth and geographic distribution. Thus, determine the suitability of a crop for a particular location, cropping pattern, management practices, and levels of inputs needed. Under favorable environment crops perform best and is least cost to produce. Hence, in order to maximize the production of any crop, it is important to understand environmental factors that affect plant growth and development (Gemechu et al., 2016). Therefore, impact of different abiotic stresses needs to be assessed in order to design appropriate breeding strategies.

\section{Breeding faba bean for soil acidity stress tolerance}

Soil acidification is a worldwide problem. Approximately $30 \%$ of the world's total land area and more than $50 \%$ of the world's potentially arable lands, particularly in the tropics and subtropics are affected by soil acidity (Kochian et al., 2004). Soil acidity is a major production constraint of crops in general and faba bean in particular in the highlands of Ethiopia (Mesfin, 2020). It is a serious threat to crop production in most high lands of Ethiopia in general and in Oromia regional state in particular and about $40.9 \%$ of the total arable land of Ethiopia is affected by soil acidity (Abdenna et al., 2007) which covers 95\% of the cropped area. Currently, it becomes the major production limiting factor of faba bean in the highlands of Ethiopia (Mesfin et al., 2019). The low yields in such soils could mainly be either due to the deficiency of nutrients, such as P, Ca and Mg (Dodd and Mallarino, 2005), or toxicity of Al, Fe and Mn (Sharma, 2004). Furthermore, Getachew et al. (2005) reported that acid soils could expose faba bean to greater chocolate spot infection thereby reducing yield.

The highlands of Ethiopia are the most affected region by soil acidity due to high amount of rainfall that exceeds evapotranspiration that leaches considerable amounts of exchangeable bases from the soil surface. As a result, most of the soils have a $\mathrm{pH}$ range of 4.5 to 5.5; contain low organic matter and nutrient availability (Temesgen et al., 2011). Practically, soil pH between 6.6 and 7.3 are considered as neutral; 5.6 to 6.5 are moderately acid and below 5.5 strongly acid (Alemu et al., 2016). Faba bean grows best in soils with pH ranging from 6.5 to 9.0 (Jensen et al., 2010), and is considered to perform poorly at a pH values of 5 or less (French \& 
White, 2005). Nevertheless, some accessions remain productive when soil pH is as low as 4.5 (Singh et al., 2012). However, the productivity of faba bean is constrained by low soil $\mathrm{pH}$ associated with low $\mathrm{P}$ availability (Dodd and Mallarino, 2005). The low availability of $\mathrm{P}$ in acid soil is associated with p-fixation.

In order to overcome low production of faba bean on acidic soils, different methods can be employed ranging from liming of soils (Achalu et al., 2013) to that of selecting tolerant host, tolerant and effective Rhizobia species to achieve effective symbiosis (Mulissa and Fassil, 2011). Acid soil can be managed by the application of lime and the effect of $\mathrm{Al}^{3+}$ toxicity is ameliorated by the use of P-containing fertilizers (Atemkeng et al., 2011). However these options are not available where farmers are poor and less effective when cultivars are sensitive (Sun et al., 2008). Hence, choice of acid-tolerant crop varieties and use of compost and farm manure may further reduce the amounts of lime required and make farming more attractive (Buni, 2014). As cultivated crops vary in their tolerance to soil acidity, selecting and growing species and variety adaptable to acidic soils could be one solution (Scott et al., 1997).

Faba bean is generally less adapted to acid soil environments and improving acid soil tolerance of faba bean to reduce the dependence of small scale farmers on lime and nutrient inputs is a major challenge. Even as reported by Zheng (2010) that subsoil acidity is harder to address than that of topsoil. However, efforts to develop adapted genotypes indicate that there are genotypic differences in soil acidity stress resistance in the faba bean genotypes (Kiflemariam et al., 2017). Likewise, common bean varieties with the capacity to tolerate acidic soil conditions also produce high yields in areas where liming is not feasible due to high acidity conditions in the subsoil. Soil acidity problems for common bean production can be overcome by growing genotypes which are adapted to acid soil condition in circumstances where other soil amendment strategies are not readily practical (Assady et al., 2005). Therefore, this holds true to develop faba bean cultivars adapted to acid soil as a promising alternative since use of lime is beyond the reach of most smallholder farmers, use of acid tolerant varieties remains the cheapest method for farmers.

\section{Breeding faba bean for drought stress tolerance}

Drought is one of the major abiotic stresses that are a threat to crop production worldwide and it impairs the growth and yield of plants (Manzer et al., 2015). It can be resulted by other abiotic stresses as well as global warming (Blum, 2011). Dry lands cover over $40 \%$ of the world (Mortimore et al., 2009) and more that 50\% of the average yield of most major crops is lost due to drought stress (Zlatev and Lidon, 2012). Climate change will lead to increased temperatures and changed precipitation patterns in the world (khazaei, 2014). Faba bean is impacted by climate change, is believed to be relatively sensitive to water deficit among legume species (Khan et al., 2010). It is highly responsive to irrigation (Oweis et al., 2005), but in most production regions it is rarely irrigated and mostly depends on stored soil moisture and rainfall for its growth and development.

Drought stress causes inhibition of photosynthesis by altering pathway regulation by stomatal closure and decreasing flow of $\mathrm{CO}_{2}$ into mesophyll tissues and also by impairing the activity of ribulose-1, 5-bisphosphate carboxylase /oxygenase (Bota et al., 2004). Also, respiration, translocation, ion uptake, carbohydrates, nutrient assimilation and growth promoters are disturbed under stress (Farooq, 2008). Plant tolerance to abiotic stresses is a complex trait, involving a range of molecular, biochemical and physiological mechanisms (Razmjoo et al., 2008). However, the response of plants to stresses depends on species and genotypes, the length and severity of water deficit, and development stage (Barnabás et al., 2008).

In Ethiopia some of the most important production complexes of faba bean are located in drought prone areas like the northern block of the country. The problem in such areas is not only the shortage in amount of rainfall but also the erratic distribution which mostly does not follow a consistent pattern of occurrence and there is high temporal and spatial variability in terms of severity, timing and duration of stress (Gemechu et al., 2016). Crop productivity adversely influenced by rainfall distribution than the total amount received in the growing season. Rainfall distribution pattern may follow different circumstances but the most important ones in parts of Africa include early, intermittent, terminal and a sort of continuous drought throughout the growing season. Therefore, cultivars successful in one dry year may fail in another, or cultivars tolerant to terminal drought may not be tolerant to intermediate drought, or to drought occurring in early season (Gemechu et al., 2016).

In order to improve crop performance, it is essential to understand how crop species respond and adapt to drought conditions. The key to drought adaptation for plant breeders and crop physiologists is modifying the morphology and physiology of a crop to its environment in order to manage water economy through stomata and regulation of water uptake by roots (khazaei, 2014). Under drought stress particular emphasis has been given to regulation of symbiotic nitrogen fixation in nodulated legumes (Singh et al., 2012). Drought adaptation is a complex quantitative trait (Khan et al., 2010) controlled by several genes and breeding for it requires the combination of conventional and molecular strategies (Chaves et al., 2003).

Thus, development of drought-adapted faba bean genotypes is an essential mission to improve yield and its stability in this crop, but progress has been relatively slow compared to other crops due to lack of efficient screening methods (Stoddard et al., 2006). Wide genotypic variation in water stress response has been reported in 
this crop (Khan et al., 2007), indicating the potential for breeding of drought-prone environments. However, field phenotyping for drought response is costly (when rain-exclusion shelters have to be established and maintained) and time-consuming and often produces unreliable output due to seasonal variation, since periods of drought vary in length, timing and intensity (Khan et al., 2007). In contrast, screening under controlled environment provides the potential for rapid response and uniform conditions. An ideal phenotyping method should be fast, low-cost, non-destructive, accurate and working on several samples (Monneveux et al., 2014). There should be a link to translate laboratory findings in controlled conditions to the field and a novel genotype should also perform well in field conditions in order for the breeding program to be successful (Passioura, 2012). Therefore, breeding for drought stress needs to consider a combination of traits for drought stress like selection for earliness and other drought related traits needs to be employed in order to improve faba bean yield and its stability under drought stress.

The use of combination of optimum and stress environments in breeding for stress is mandatory. The optimum environment indicates the potential yield of genotypes while the stress environment indicates the stress tolerance level of genotypes. The yield from these two environments used to calculate different stress tolerance indices.

Any drought resistance related trait
F

$\mathbf{F}_{4}$

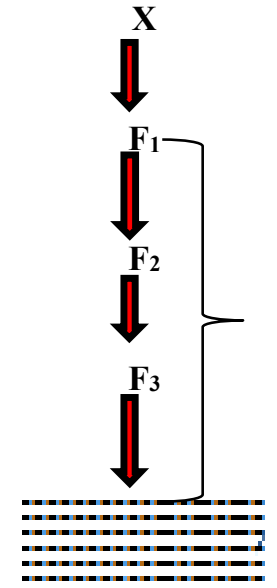

$F_{6}$ and $F_{7}$

$\mathbf{F}_{5}$
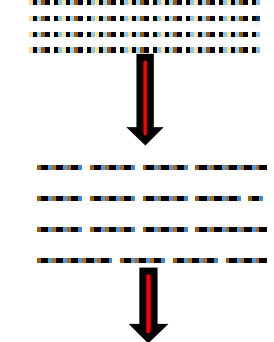

Line B

High yield

F1-F4 generation advanced under optimum environment

1. Space planted under optimal moisture

2. A large number of individual plants selected and harvested separately, inferior ones rejected

1. Individual plant progenies grown under moisture stress

2. Progenies evaluated for moisture stress only

3. Superior progenies for moisture stress selected and harvested separately-may be repeated

1. Selected progenies grown under optimum moisture

2. Superior plants selected based on yield, yield attributes and quality traits- this may be repeated at F7

Preliminary yield trial under moisture stress
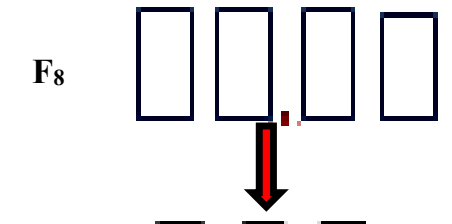

F9-F $_{11}$

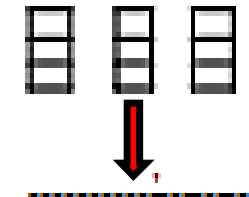

$\mathbf{F}_{12}$

Multi-location yield trial-wide range of environments-drought resistant and high yielding varieties identified and recommended

\section{Seed multiplication for distribution}

Figure-1. A breeding approach for drought resistance based on combined use of optimum and moisture stressed environments 


\section{Breeding faba bean for water logging problem}

Ethiopia is estimated to have 12.61 million hectares of vertisols of which 63\% is located in the highlands (Berhanu, 1985). Waterlogging is a major constraint of faba bean production in the highland vertisols of Ethiopia (Gemechu et al., 2001). Drainage using broad bed and furrow (BBF) cultivation enables management of excess water for increased production (Gemechu et al., 2001). However, BBF must be repeated each season and is expensive. It is affordable only for farmers who can purchase a broad bed maker. In Ethiopia, most of the faba bean yield comes from production with flat beds. Selection of genotypes under BBF is efficient for identification of genotypes for the flatbed conditions. Breeders generally prefer to work under favorable conditions because heritability and expected genetic gains from selection and level of success is usually lower under stressed conditions (Singh, 1990). Breeding of productive genotypes under waterlogging could be one of the stable alternatives to solve the problems under excess moisture management (Gemechu and Mussa, 2009).

To alleviate the production problems of faba bean in vertisol areas (waterlogging problem areas) by using direct selection method (screening of genotypes under water logging condition) that best suits for water logging condition and varieties that tolerate this stress condition have been released in different years. To tackle the problem of waterlogging the national faba bean research in Ethiopia developed and released six faba bean varieties (Selale, Wayu, Wolki, Hachalu, Didi'a, Ashebeka) at national level (Tadele, 2019). These varieties give high yield by resisting black root rot and foot rot that contribute to the low productivity of faba bean at waterlogging environments. This breeding success was achieved due to use of different genetic variability creation mechanisms such as local collection at vertisol areas, screening of genotypes under sick plot for fusarium solani and hybridization.

\section{Breeding Strategy for Resistance to Abiotic Stresses}

The situation of crop production in the $21^{\text {st }}$ century does not look bright (Pinstrup-Andersen et al., 1999) due to many biotic and abiotic stresses that significantly reduce crop yields. Thus, it is essential to understand how plants respond to different abiotic stresses in order to improve crop performance. This difficult task can only be achieved by integrating conventional breeding and biotechnological approaches (Singh et al., 2012). Plant breeding plays an important role for increasing crop yield and stress adaptation (Moose and Mumm, 2008). It describes methods for the creation, selection, and fixation of superior plant phenotypes for the development of improved cultivars. However, to improve the productivity of crops genetic modification is better than the continual manipulation of the growing environment because of cost particularly to the resource-poor farmers who cannot afford production inputs. Therefore, to maximize gains from breeding efforts, varietal selection should be at actual target production environments as there is no purpose in breeding drought-resistant genotypes in drought-free environments or frostresistant genotypes in frost-free environments (Gemechu, 2007). Similarly, breeding for acid soil and waterlogging tolerant genotypes has to be done in acid prone and waterlogging problem environments rather than acid free and drained environments, respectively.

The breeding strategy targets specific adaptation for exploiting genetic potential of cultivars that are responsive to optimum environments and for widely adapting varieties that consistently perform better under various environments. Specific breeding of crop cultivars that will adapt under resource poor environments like the drought, nutrient deficient and soil acidity-prone areas is necessary. This strategy includes breeding genotypes for resource use efficiency; genotypes that are able to mobilize the limiting resources like nutrient and moisture in greater amounts and better use for yield formation. The ultimate goal for specific adaptation is not to exploit the genetic potential of the crop rather to fit cultivars to the existing environment by developing varieties with modest resources demand and having resistance under stressed conditions (Gemechu et al., 2016). Likewise, the primary goals of faba bean breeding are, those of like any other crop, to improved yields, seed quality (e.g. low vicineconvicine and tannin-free), adaptation to biotic and abiotic stresses (Torres et al., 2012).

\section{Conclusion}

Faba bean is one of the oldest crops grown by man and it is used as a source of protein in human diets, as fodder and a forage crop for animals, and for available nitrogen in the soil. Despite the various benefits and availability of high yielding varieties in Ethiopia, the productivity of faba bean has remained very low compared to its potential. The low productivity of the crop is attributed to susceptibility to biotic and abiotic stresses coupled with poor crop management provided by the farmers in which abiotic stress take the lions share.

The growth and yield of faba bean is highly hindered by abiotc factors like soil acidity, drought stress and waterlogging problem that leads to low production of the crop in Ethiopia. Drought and Soil acidity are worldwide problems, and sensitivity to acid soils limits the usage of faba bean in some cropping systems. Likewise, more that $50 \%$ of the average yield of most major crops is lost due to drought stress and faba bean is among the sensitive crops. Soil acidity in the highlands and waterlogging on vertisol areas are the major production constraints of faba bean in Ethiopia and also drought in the northern block of the country.

The production constraints of faba bean due to soil acidity, drought and waterlogging problems can be reduced 
by using lime, supplemental irrigation and drainage, respectively.

In conclusion, the purpose of breeding for abiotic stress is to combat stresses on the target environment and fit genotypes for specific environments. Thus, breeding for acid soil, drought and waterlogging tolerant genotypes has to be carried out in acid prone, moisture stress and waterlogging problem environments, respectively. Therefore use of decentralized breeding approach is the best option to combat specific stresses on the hotspot environments rather than doing all the breeding activities at non-hotspot areas.

\section{Conflicts of Interest}

The author declares that there is no conflict of interest.

\section{Reference}

Abdenna D, CW Negassa and G Tilahun, 2007. Inventory of Soil Acidity Status in Crop Lands of Central and Western Ethiopia. "Utilization of diversity in land use systems: Sustainable and organic approaches to meet human needs".

Achalu C, G Heluf, K Kibebaw, T Abi, 2013. Changes in soil chemical properties as influenced by liming and its effects on barely grain yield on soils of different land use system of East Wollega, Ethiopia. World Applied Science Journal 24:1435-1441.

Ali AE, GE Ahmed and EB Elhardallou, 1982. Faba bean and their role in diet in Sudan. In faba bean improvement (Hawtin, G. and Webb, C. ed) P. 318 ICARDA, Matinus

Asfaw T, G Tesfaye and D Beyene, 1994. Genetics and breeding of faba bean. In: Asfaw, Telaye. (Eds). Cool season food legumes in Ethiopia. Proceedings: First National Cool season food legume review conference, Addis Ababa, Ethiopia. Pp. 122-137.

Asefa K, A Fassil, PC Prabu, 2010.Characterization of acid and salt tolerant rhizobial strains isolated from faba bean fields of Wollo, Northern Ethiopia. Journal of Agricultural Science and Technology 12: 365- 376.

Assady B, HR Dorri and S Vaezi, 2005. Study of genetic diversity of bean (Phaseolus vulgaris L.) genotypes by multivariate analysis methods. The first Iranian Pluses symposium, research centre for plant sciences. Ferdowsi University of Mashhad, Mashhad, Iran. pp: 650.

Atemkeng MF, TJ Muki, J Park and J Jifon, 2011. Integrating molecular tools with conventional breeding strategies for improving phosphorus acquisition by legume crops in acid soils of sub-Saharan Africa. Biotechnology and Molecular Biology Reviews 6:142-154.

Barnabás B, K Jäger and A Fehér, 2008. The effect of drought and heat stress on reproductive processes in cereals. Plant Cell Environ. 31, 11-38.

Berhanu D, 1985. The Vertisols of Ethiopia: Their Properties, Classification and Management. Fifth meeting of the Eastern African soil correlation and land evaluation subcommittee, 4-10 December 1983, Wad Medani, Sudan. World soil resources report 56. FAO (Food and Agriculture Organization of the United Nations), Rome, pp. 31-54.

Blum A, 2011. Drought resistance. Is it really a complex trait? Funct. Plant Biol., 38, 753-757.

Bond DA, DA Lawes and JS Stephens, 1985. Faba Bean (Vicia faba L.). pp. 199-265. In: R.J. Summerfield and E.H. Roberts (ed.), Grain Legume Crops. William Collins Sons Co. Ltd. 8 Grafton Street, London, WIX 3LA, UK.

Bota J, H Medrano and J Flexas, 2004. Is photosynthesis limited by decreased Rubisco acivity and RuBP content under progressive water stress? New Phytol. 162, 671-681.

Buni A, 2014. Effects of Liming Acidic Soils on Improving Soil Properties and Yield of Haricot Bean. J Environ Anal Toxicol 4: 248. doi: 10.4172/2161-0525.1000248.

Chaves MM, JP Maroco and JS Pereira, 2003. Understanding plant responses to drought - from genes to the whole plant. Funct Plant Biol 30:239-264

Crépon K, P Marget, C Peyronnet, B Carrouée, P Arese and G Duc, 2010. Nutritional value of faba bean (Vicia faba L.) seeds for feed and food. Field Crops Res., 115 (3): 329-339.

CSA (Central Statistics Agency), 2017. Agricultural Sample Survey, Area and Production of Crops, Addis Ababa, Ethiopia.

Dodd JR and AP Mallarino, 2005. Soil-test phosphorus and crop grain yield responses to long-term phosphorus fertilization for corn-soybean rotations. Soil Sci. Soc. Amer. J. 69:1118-1128.

Duc G, M Pascal and A Paolo, 2011. Breeding priorities for improved nutritional value of Vicia faba seeds. Grain legumes, (56), 17-18.

FAOSTAT (Food and Agriculture Organization Statistics), 2018. Statistical database of agricultural production. Rome, Italy.

Farooq M, SMA Basra, A Wahid, ZA Cheema, MA Cheema, A Khaliq, 2008. Physiological role of exogenously applied glycinebetaine in improving drought tolerance of fine grain aromatic rice (Oryza. sativa L.). J. Agron. Crop Sci. 194, 325-333. 
French B and P White, 2005.Soil and environmental factors affecting pulse adaptation in Western Australia. Australia Journal of Agricultural Research 50:375-387.

Gemechu K, A Belay and J Mussa, 2001. Efficiency of drained selection environment for improving grain yield in faba bean under undrained target environments on Vertisol. Euphytica 122 (2): 279-285

Gemechu K and J Mussa, 2002. Comparision of three secondary traits as determinants of grain yield in faba bean on waterlogged Vertisols. Journal of Genetics and Breeding, 56: 317-326.

Gemechu K, 2007. Concerns on Mismatches between Environments of Selection and Production of Crop Varieties in Ethiopia. East African Journal of Sciences. Volume 1 (2) 93-103.

Gemechu K, F Asnake and E Million, 2016. Reflections on Highland Pulses Improvement Research in Ethiopia. Ethiopian Journal of Agricultural Sciences. EIAR 50 ${ }^{\text {th }}$ Year Jubilee Anniversary Special Issue: 17-50

Getachew A, B Taye and T Agajie, 2005. P fertilizer and FYM effect on the growth and yield of faba bean and some chemical properties in acidic nitisols of centeral high land of Ethiopia. Ethiopian journal of natural resources, 7: 23-39.

Hanelt P and D Mettin, 1989. Biosystematics of the genus Vicia L. (Leguminosae). Annu. Rev. Ecol. Syst., 20:199223.

IFPRI, 2010. Pulses value chain in Ethiopia: Constraints and opportunities for enhancing exports. Working Paper. International Food Policy Research Institute (http:/ /www.ifpri.org/ sites/default/files/publications/ethiopian agsectorwp pulses.pdf)

Jensen ES, MB Peoples and H Hauggaard-Nielsen, 2010. Faba bean in cropping systems. Field Crops Research 115(3):203-216, DOI 10.1016/j.fcr.2009.10.008.

Khan HR, W Link, TJH Hocking and FL Stoddard, 2007. Evaluation of physiological traits for improving drought tolerance in faba bean (Vicia faba L.). Plant Soil 292:205-217

Khan HR, JG Paull, KHM Siddique and FL Stoddard, 2010. Faba bean breeding for droughtaffected environments: A physiological and agronomic perspective. Field Crops Research 115:279-286

Khazaei H, 2014. Leaf traits associated with drought adaptation in faba bean (Vicia faba L.). Doctoral thesis. University of Helsinki Department of Agricultural Sciences Faculty of Agriculture and Forestry. Helsinki.

Kochian LV, OA Hoekenga and MA Piners, 2004. How do crop plants tolerate acid soils: Mechanism of aluminum tolerance and phosphorus efficiency? Annual Review of Plant Biology 55: 459-493.

Maalouf F, 2011. Faba bean improvement at ICARDA: Constraints and challenges. Grain legumes, (56), 13-14.

Siddiqui MH, MY Al-Khaishany, MA Al-Qutami, HM Al-Whaibi, A Grover, HM Ali, MS Al-Wahibi and NA Bukhari, 2015. Response of Different Genotypes of Faba Bean Plant to Drought Stress. International Journal of Molecular Science 16, 10214-10227; doi: 10.3390/ijms160510214.

McVicar R, D Panchuk, C Brenzil, S Hartley, P Pearse, A Vandenberg, 2013. Faba bean Gov. Saskatchewan, Agriculture, Crops.

Mesfin T. 2019. Breeding achievements of faba bean (Vicia faba L.) and its impact in the livelihood of Ethiopian farmers. Inter J Agri Biosci, 8(5): 263-269. www.ijagbio.com

Mesfin T, M Wassu and J Mussa, 2019. Genetic Variability on Grain Yield and Related Agronomic Traits of Faba Bean (Vicia faba L.) Genotypes under Soil Acidity Stress in the Central Highlands of Ethiopia. Chemical and Biomolecular Engineering, 4(4): 52-58. doi: 10.11648/j.cbe.20190404.12

Mesfin T. 2020. Impacts of Soil Acidity on Growth Performance of Faba bean (Vicia faba L.) and Management Options. Acad. Res. J. Agri. Sci. Res. 8(4): 423-431. DOI: 10.14662/ARJASR2020.275.

Metayer, 2004. Vicia faba breeding for sustainable agriculture in Europe. Gie feverole.

MoALR (Ministry of Agriculture and Livestock Resource), 2017. Plant variety release, protection and seed quality control directorate. Crop variety register, Issue No. 20. Addis Ababa, Ethiopia.

Monneveux P, JM Ribaut and A Okono, 2014. Drought phenotyping in crops: from theory to practice. Frontier Ebooks.

Moose SP and RH Mumm, 2008. Molecular plant breeding as the foundation for $21^{\text {st }}$ century crop improvement. Plant Physiol 147:969-977

Mortimore M, S Anderson, L Cotula, J Davies, K Faccer, C Hesse, J Morton, W Nyangena, J Skinner and C Wolfangel, 2009. Dryland Opportunities: A new paradigm for people, ecosystems and development, IUCN, Gland, Switzerland; IIED, London, UK and UNDP/DDC, Nairobi, Kenya. 86 p

Mussa J and K Gemechu, 2006. Vicia faba L. pp. 195-199. In Brink M. and Belay G. (eds.). Plant Resources of Tropical Africa 1: Cereals and Pulses. PROTA Foundation, Wageningen, Netherlands/Backhuys Publishers, Leiden, Netherlands/CTA, Wageningen, Netherlands. ISBN 90-5782-170-2.

Mussa J, G Dereje and K Gemechu, 2008. Procedures of Faba Bean Improvement through Hybridization. Technical Manual No. 21, Ethiopian Institute of Agricultural Research, 48pp.

Oweis T, A Hachum and M Pala, 2005. Faba bean productivity under rainfed and supplemental irrigation in northern Syria. Agr Water Manag 73:57-72.

Passioura JB, 2012. Phenotyping for drought tolerance in grain crops: when is it useful to breeders? Funct Plant 
Biol 39:851-859

Pinstrup-Andersen P, R Pandya-Lorch and MW Rosegrant, 1999. World food prospects: critical issues for the early twenty-first century. International Food Policy Research Institute, Washington DC, USA

Razmjoo K, P Heydarizadeh and MR Sabzalian, 2008. Effect of salinity and drought stresses on growth parameters and essential oil content of Matricaria. chamomile. Int. J. Agric. Biol., 10, 451-454.

Sahile S, F Chemeda, PK Sakhuja and A Sied, 2008. Effect of mixed cropping and fungicides on chocolate spot (Botrytis fabae) of faba bean (Vicia faba) in Ethiopia. Crop Protection, 27:275-282.

Sainte M, 2011.The magazine of the European Association for Grain Legume Research. Issue No. 56 Model Legume Congress, France, 15-19 May 2011.

Scott BJ, MK Conyers, GJ Poile and BR Cullis, 1997. Subsurface acidity and liming affect yield of cereals. Australian Journal of Agricultural Research 48, 843-854.

Sharma BD, H Arora, R Kumar and VK Nayyar, 2004. Relationship between soil characteristics and total and DTPA-extractable micronutrients in Inceptisols of Punjab. Communication in Soil Science and Plant Analysis 35: 799-818.

Singh BD, 1990. Plant breeding: Principles and methods. Kalyani Publishers, New Delhi Ludhiana, India.

Singh AK, BP Bhatt, A Upadhyaya, S Kumar, PK Sundaram, BK Singh, N Chandra and RC Bharati, 2012. Improvement of faba bean (Vicia faba L.) yield and quality through biotechnological approach: a review. African Journal of Biotechnology 11:15264-15271.

Stoddard FL, C Balko, W Erskine, HR Khan, W Link and A Sarker, 2006. Screening techniques and sources of resistance to abiotic stresses in cool-season food legumes. Euphytica 147:167- 186

Sun QB, RF Shen, XQ Zhao, RF Chen and XY Dong, 2008. Phosphorus enhances Al resistance in Al-resistant Lespedeza bicolor but not in Al-sensitive L. cuneata under relatively high Al stress. Annals of Botany 102(5):795-804 DOI 10.1093/aob/mcn166.

Temesgen D, AGetachew, K Tesfu, D Tolessa and T Mesfin, 2011. Past and present soil acidity management research in Ethiopia. A review. Paper presnted at the '2nd National Soil and Water Management Workshop', 28-31 January 2011, Addis Ababa, Ethiopia.

Thijssen MH, Z Bishaw, A Beshir and WS de Boef, 2008. Farmers, seeds and varieties: supporting informal seed supply in Ethiopia. Wageningen, Wageningen International. P.348

Torres AM, B Roman, CM Avila, Z Satovic, D Rubiales, JC Sillero, JI Cubero and MT Moreno, 2006. Faba bean breeding for resistance against biotic stresses: towards application of marker technology. Euphytica 147, 6780 .

Torres AM, CM Avila, FL Stoddard and JI Cubero, 2012. Faba bean. In: Pérez de la Vega M, Torres AM, Cubero JI, Kole C (eds) Genetics, genomics and breeding in crop plants: cool season food legumes. Science Pubs Inc, New Hampshire. pp 50-97

Winch T, 2006. Growing Food. A Guide to Food Production. Springer.

Zheng SJ, 2010. Crop production on acid soils: overcoming aluminum toxicity and phosphorus deficiency. Annals of Botany 106(1):183-184 DOI 10.1093/aob/mcq134.

Zlatev Z, and FC Lidon, 2012. An overview on drought induced changes in plant growth, water relations and photosynthesis. Emir. J. Food Agric. 24, 57-72.

Zohary D and M Hopf, 2000. Domestication of Plants in the Old World, 3rd eds. Oxford: Clarendon Press. 